\title{
Nâng cao chất lượng tăng trưởng của vùng kinh tế trọng điểm phía Nam nhìn từ góc độ kinh tế
}

\section{Improving the growth quality of the Southern key economic region from an economic perspective}

\begin{tabular}{|c|c|}
\hline \multicolumn{2}{|c|}{$\begin{array}{l}{ }^{1} \text { Trường Đại học Bà Rịa Vũng Tàu, Việt Nam } \\
\text { *Tác giả liên hệ, Email: khanhpn@ @bvu.edu.vn }\end{array}$} \\
\hline THÔNG TIN & TÓM TÁ T \\
\hline $\begin{array}{l}\text { DOI: } 10.46223 / \mathrm{HCMCOUJS} . \\
\text { econ.vi.14.3.479.2019 }\end{array}$ & $\begin{array}{l}\text { Mục tiêu của bài viết là phân tích, đánh giá chất lượng } \\
\text { tăng trường kinh tế của vùng kinh tế trọng điểm (KTTĐ) phía } \\
\text { Nam nhìn từ góc độ kinh tế. Bài viết sử dụng các chỉ tiêu kinh tế } \\
\text { để phân tích như: tốc độ tăng trưởng kinh tế, GDP bình quân đầu } \\
\text { người, cơ cấu GDP và tốc độ tăng trưởng GDP phân theo khu vực } \\
\text { kinh tế, giá tri xuất nhâp khẩu, tốc đô tăng trưởng và tỷ trong xuất }\end{array}$ \\
\hline Ngày nhận: 04/06/2019 & nhập khẩu của vùng; bằng cách sử dụng các chỉ tiêu kinh tế như \\
\hline Ngày nhận lại: 12/09/2019 & phương pháp hạch toán để xác định tỷ phần đóng góp của các \\
\hline Duyệt đăng: 13/09/2019 & $\begin{array}{l}\text { nhân tố vốn, lao động và TFP; phân tích hiệu quả vốn đầu tư } \\
\text { (ICOR), năng suất lao động và tiến bộ khoa học công nghệ; phân } \\
\text { tích năng lực cạnh tranh của các tỉnh, thành phố của vùng. Kết } \\
\text { quả cho thây, tăng trưởng của vùng có xu hướng chậm lại và thiếu } \\
\text { bền vững; tỷ trọng đóng góp của nhân tố TFP trong GDP có xu }\end{array}$ \\
\hline Tù khóa: & hướng giảm, chất lượng tăng trưởng và năng lực cạnh tranh trong \\
\hline $\begin{array}{l}\text { chất lượng tăng trưởng kinh } \\
\text { tế, vùng kinh tể trọng điểm } \\
\text { phía Nam }\end{array}$ & $\begin{array}{l}\text { điều kiện hội nhập chưa cao; chuyển dị́ch cơ cấu nội bộ các ngành } \\
\text { kinh tê còn chậm, từ đó bài viết đề xuất một số giải pháp để nâng } \\
\text { cao chất lượng tăng trưởng của vùng KTTĐ phía Nam. }\end{array}$ \\
\hline
\end{tabular}

\begin{abstract}
The objective of this paper is to analyze and evaluate the quality of economic growth in the Southern key economic region from an economic perspective. Economic indicators such as economic growth rate, per capita GDP, GDP structure and GDP growth rate by economic sector, import-export value, speed regional growth and import-export proportion were used for analysis. Accounting methods were used to determine the contribution of the regional capital, labor and TFP, to analyze the efficiency of investment capital (ICOR), labor productivity and scientific and technological progress as well as the competitiveness of the provinces and cities of the region. The
\end{abstract}


Keywords:

quality of economic growth, Southern key economic region results show that regional growth tends to be slow and unsustainable; The contribution of TFP factor in GDP tends to decrease, the quality of growth and competitiveness in terms of integration is not high; The internal restructuring of economic sectors is still slow, from which the paper proposes some solutions to improve the growth quality of the Southern key economic region.

\section{Giới thiệu}

Qua hơn 20 năm quy hoạch tổng thể phát triển kinh tế - xã hội của vùng kinh tế trọng điểm (KTTĐ), vùng KTTĐ phía Nam (bao gồm 8 tỉnh, thành phố: TP HCM, Bình Dương, Đồng Nai, BRVT, Bình Phước, Tây Ninh, Long An và Tiền Giang) đã đạt được những thành tựu rất quan trọng về phát triển kinh tế - xã hội (năm 2017, sản xuất hơn $45 \%$ GDP, gần $46 \%$ kim ngạch xuất khẩu cả nước; đóng góp gần $50 \%$ ngân sách quốc gia, tổng sản phẩm quốc nội tính theo đầu người cao gần gấp 2,1 lần mức bình quân cả nước). Tăng trưởng kinh tế diễn ra nhanh, bên cạnh đó là những cải thiện rõ rệt về một số chỉ tiêu quan trọng của chất lượng tăng trưởng kinh tế như: cơ cấu kinh tế chuyển dịch theo hướng tích cực, hội nhập kinh tế quốc tế ngày càng sâu rộng, đời sống người dân được nâng cao, thành tích xóa đói giảm nghèo được cộng đồng quốc tế đánh giá cao... Tuy nhiên, nhìn chung chất lượng tăng trưởng kinh tế của vùng KTTĐ phía Nam còn thấp. Đặc biệt có những thời điểm có dấu hiệu không ổn định, điều đó thể hiện ở chỗ bên cạnh sự giảm sút về tốc độ tăng trưởng kinh tế và còn rất nhiều vấn đề đặt ra, cần được giải quyết. Vì vậy, việc đánh giá, phân tích thực trạng chất lượng tăng trưởng của vùng KTTĐ phía Nam nhìn từ góc độ kinh tế sẽ góp phần đề xuất một số giải pháp, chính sách sử dụng hiệu quả các nguồn lực để nâng cao chất lượng tăng trưởng kinh tế của vùng KTTĐ phía Nam.

\section{Cơ sở lý thuyết}

\subsection{Khái niệm chất lựng tăng trưởng kinh tế}

Hiện nay, vẫn chưa có một quan niệm thống nhất về chất lượng tăng trưởng, bởi đây là khái niệm khá rộng và mang tính tổng quát, bao trùm nhiều nội dung về kinh tế, chính trị, thể chế, xã hội và môi trường.

Theo nghĩa hẹp, chất lượng tăng trưởng kinh tế có thể hiểu đó là: hiệu quả của đầu tư, đánh giá qua chỉ tiêu tỷ lệ gia tăng vốn trên sản lượng (ICOR), chất lượng giáo dục, chất lượng dịch vụ công, quản lý xã hội, GDP, cơ cấu kinh tế, sức cạnh tranh của từng sản phẩm, từng doanh nghiệp, từng ngành và cả nền kinh tế hoặc coi tương đương với khái niệm năng suất nhân tố tổng hợp, đánh giá năng suất nhân tố tổng hợp (TFP). Như vậy, chất lượng tăng trưởng là thuộc tính bên trong của quá trình tăng trưởng kinh tế, thể hiện qua các chỉ tiêu phản ánh hiệu quả đạt được mặt số lượng của tăng trưởng và khả năng duy trì nó trong dài hạn.

Theo nghĩa rộng, chất lượng tăng trưởng có thể tiến tới nội hàm của quan điểm về phát triển bền vững, chú trọng tới tất cả ba thành tố đó là: kinh tế, xã hội và môi trường. Như vậy, 
tăng trưởng trở nên toàn diện hơn và được nâng cao một bước so với trước. Nói đến tăng trưởng không chỉ đơn thuần là tăng thu nhập bình quân đầu người, mà hai mục tiêu khác không kém phần quan trọng là duy trì tốc độ tăng trưởng cao trong dài hạn và tăng thu nhập phải gắn với tăng chất lượng cuộc sống hay tăng phúc lợi và xoá đói giảm nghèo. Điều này cũng có nghĩa, tăng trưởng không không nhất thiết phải đạt tốc độ tăng trưởng quá cao mà chỉ cần cao ở mức độ hợp lý nhưng bền vững.

Theo quan điểm của Ngân hàng Thế giới và các nghiên cứu thực nghiệm của một số nhà kinh tế học như: R. Lucas (Nobel Kinh tế năm 1995), Amartya Sen (Nobel Kinh tế 1998) và $\mathrm{J}$. Stinglitz (Nobel Kinh tế 2001) cho rằng, chất lượng tăng trưởng kinh tế tập trung chủ yếu ở sáu tiêu chuẩn:

Một là, tốc độ tăng trưởng kinh tế ổn định trong thời gian tương đối dài và tránh được các biến động từ bên ngoài.

Hai là, tăng trưởng kinh tế phải đảm bảo nâng cao hiệu quả kinh tế và sức cạnh tranh của nền kinh tế.

Ba là, tăng trưởng kinh tế theo chiều sâu, được thể hiện ở sự đóng góp của nhân tố TFP cao và không ngừng gia tăng.

Bốn là, tăng trưởng kinh tế phải đi kèm với phát triển môi trường bền vững.

Năm là, tăng trưởng kinh tế phải đạt mục tiêu cải thiện phúc lợi xã hội và giảm được đói nghèo.

Sáu là, tăng trưởng kinh tế phải hỗ trợ cho thể chế dân chủ luôn đổi mới, đến lượt nó thúc đẩy tăng trưởng kinh tế ở tỷ lệ cao hơn (N. H. Nguyen, 2015).

\subsection{Một số quan niệm đáng chú ý về chất luọng tăng trương kinh tế}

Thứ nhất, quan niệm chất lượng tăng trưởng kinh tế là phát triển bền vững.

Thư hai, chất lượng tăng trưởng kinh tế theo quan niệm hiệu quả.

Thư $b a$, quan niệm chất lượng tăng trưởng kinh tế là nâng cao phúc lợi của công dân và gắn liền tăng trưởng với công bằng xã hội.

Thứ tux, quan niệm chất lượng tăng trưởng kinh tế là cơ cấu và chuyển dịch cơ cấu của tăng trưởng kinh tế.

Thứ năm, quan niệm chất lượng tăng trưởng kinh tế là năng lực cạnh tranh của nền kinh tế, ngành hoặc doanh nghiệp được xem xét.

Thứ sáu, quan niệm chất lượng tăng trưởng kinh tế là thể chế dân chủ trong môi trường chính trị xã hội của nền kinh tế.

Như vậy, từ các quan điểm và khái niệm trên, tác giả có thể đưa ra khái quát khái niệm về chất lượng tăng trưởng kinh tế đó là: Chất luợng tăng trương kinh tế bao gồm tăng truởng kinh tế và phát triển bền vũng, liên quan đến bốn thành tố đó là kinh tế, môi trương, thể chế và 
xã họi. Một nền kinh tế có chất lượng tăng trương tốt khi có tăng trương kinh tế hợp lý và ổn định, môi truòng được bảo vệ bền vũng, hiệu lực quản lý của nhà nước bảo đảm phù hợp và chất lượng cuộc sống người dân được nâng cao.

\subsection{Các chỉ tiêu phản ánh hiệu quả kinh tế}

Một là, chỉ tiêu phản ánh hiệu quả sủ dụng vốn (ICOR)

ICOR phản ánh việc tạo thêm một đơn vị tăng trong sản lượng (GDP) thì cần tăng lên bao nhiêu đơn vị vốn đầu tư thực hiện. Theo World Bank (2012), ICOR có thể được tính bằng công thức sau:

$$
I C O R=\frac{\Delta K}{\Delta Y}=\frac{\frac{\Delta K}{Y}}{\frac{\Delta Y}{Y}}=\frac{\frac{I}{Y}}{\frac{\Delta Y}{Y}}
$$

Trong đó: $\mathrm{K}$ là vốn; Y là sản lượng (GDP); $\Delta K$ là sự thay đổi lượng vốn giữa hai thời kỳ; $\Delta Y$ là sự thay đổi sản lượng giữa hai thời kỳ; I là chỉ tiêu đầu tư.

ICOR càng cao thì phản ánh nền kinh tế đó sử dụng vốn càng kém hiệu quả. Tuy nhiên cần lưu ý trong việc sử dụng ICOR khi so sánh, vì ở mỗi giai đoạn phát triển khác nhau, tỷ lệ kết hợp giữa vốn và lao động sẽ khác nhau. Thông thường, ICOR sẽ thấp khi nền kinh tế ở giai đoạn đầu của quá trình phát triển vì khi đó các ngành sản xuất thâm dụng lao động. ICOR có xu hướng gia tăng khi nền kinh tế phát triển, chuyển từ các ngành thâm dụng lao động sang thâm dụng vốn (H. T. Nguyen, 2017).

Hai là, chỉ tiêu năng suất nhân tố tổng hợp (TFP)

TFP phản ánh sự đóng góp của các nhân tố như tiến bộ công nghệ, kỹ năng quản lý, kiến thức - kinh nghiệm - kỹ năng của người lao động vào tăng trưởng sản lượng.

Theo Solow (1957), TFP được ước tính bằng cách lấy tăng trưởng sản lượng trừ đi phần tăng trưởng do tích luỹ vốn và gia tăng lực lượng lao động.

TFP được tính theo công thức:

$$
\begin{gathered}
g \mathrm{Y}=\mathrm{a}+\mathrm{wKgK}+\mathrm{wLgL} \\
\text { Do đó: } \mathrm{TFP}=\mathrm{a}=\mathrm{gY}-(\mathrm{wKgK}+\mathrm{wLgL})
\end{gathered}
$$

Trong đó: $\mathrm{gY}, \mathrm{gK}$ và gL là tốc độ tăng trưởng của GDP, vốn và lao động; $\mathrm{wL}$ và wK là tỷ trọng tiền lương và sinh lợi của vốn trong giá trị gia tăng; a là tăng trưởng TFP.

TFP được coi là nhân tố chất lượng của tăng trưởng hay tăng trưởng theo chiều sâu. Nếu TFP tăng nhanh và chiếm tỷ trọng đóng góp cao cho tăng trưởng kinh tế thì sẽ đảm bảo duy trì tăng trưởng kinh tế trong dài hạn và tránh được những biến động từ nhân tố bên ngoài $(\mathrm{H}$. $\mathrm{T}$. Nguyen, 2017).

Ba là, chỉ tiêu hiệu quả sủ dụng lao động - năng suất lao động (NSLĐ) 
Theo Báo cáo năng lực cạnh tranh Việt Nam (Tổng cục thống kê, 2010), NSLĐ được định nghĩa là GDP chia cho số lao động. NSLĐ tăng lên là biểu hiện của tính hiệu quả của nền kinh tế gia tăng. Đây là nhân tố đảm bảo cho việc gia tăng thu nhập và mức sống của người lao động.

NSLĐ cũng được định nghĩa trên cơ sở của hàm sản xuất:

$$
\mathrm{Y} / \mathrm{L}=\mathrm{A} \cdot \mathrm{F}(\mathrm{K} / \mathrm{L}, \mathrm{H} / \mathrm{L}, \mathrm{N} / \mathrm{L})
$$

Trong đó: Y/L là GDP/lao động; $\mathrm{K} / \mathrm{L}$ là trang bị vốn vật chất/lao động; $\mathrm{H} / \mathrm{L}$ là trang bị vốn con người/lao động; $\mathrm{N} / \mathrm{L}$ là trang bị tài nguyên thiên nhiên/lao động; $\mathrm{A}$ là đại diện cho trình độ công nghệ của nền kinh tế (H. T. Nguyen, 2017).

\section{Phương pháp nghiên cứu}

Tác giả nghiên cứu sử dụng số liệu thứ cấp của 8 tỉnh/thành phố thuộc vùng KTTĐ phía Nam trong giai đoạn 2013 - 2017 (5 năm), được trích dẫn từ 2 nguồn chính là: Tổng cục Thống kê và Cục thống kê địa phương. Tất cả các số liệu trên sau khi thu thập đều có sự điều chỉnh về cùng một gốc so sánh năm 2010. Tác giả phân tích, tổng hợp các số liệu điều tra thu thập được trên các đơn vị thống kê theo tiêu chí lựa chọn, từ đó xử lý số liệu; thống kê mô tả bởi các tham số đặc trưng như số tương đối, số tuyệt đối, số trung bình, mốt, trung vị, độ lệch chuẩn, tối đa, tối thiểu để phân tích, đánh giá quy mô, cơ cấu; sử dụng phương pháp dãy số thời gian trong thống kê để phân tích sự biến động về chất lượng tăng trưởng kinh tế qua các năm của các địa phương và cả vùng KTTĐ phía Nam.

(i) Sản lựng (Y) được đo bằng giá trị GDP hàng năm của các tỉnh, thành phố của vùng KTTĐ phía Nam (tính theo giá so sánh năm 2010, đơn vị tính tỷ đồng). Thước đo này được sử dụng trong nhiều nghiên cứu, điển hình như nghiên cứu của $\mathrm{Ng}$ và Leung (2004), Tran (2010).

(ii) Vốn vật chất (K): K là lượng vốn vật chất thực tế của nền kinh tế (tỷ đồng), được hình thành từ lượng vốn đầu tư của thời kỳ hiện tại kết hợp lượng vốn tích lũy của thời kỳ trước đã loại trừ yếu tố hao mòn (thường được gọi là trữ lượng vốn). Sự gia tăng tổng số vốn vật chất có tác động làm gia tăng sản lượng. Theo Krueger và Lindahl (2001) cho rằng mức GDP gốc có thể thay thế cho mức vốn vật chất ban đầu trong mô hình sản xuất Cobb-Douglas (1928), từ đó ta có thể sử dụng công thức để tính toán giá trị vốn cho các thời kỳ tiếp theo. Mức vốn vật chất các năm được tính:

$$
\mathrm{Kt}=(1-\lambda) \mathrm{Kt}-1+\mathrm{It}
$$

Trong đó: It là tổng mức vốn đầu tư toàn xã hội năm thứ $\mathrm{t}$ và là tỷ lệ khấu hao vốn cho các tỉnh/thành phố và là hằng số theo thời gian. Nghiên cứu này sử dụng GDP gốc là năm 2013 và giá trị tỷ lệ khấu hao là $=5 \%$. Cách tính $\mathrm{K}$, lựa chọn GDP làm $\mathrm{K} 0$ ban đầu, xác định giá trị hoàn toàn phù hợp và được sự ủng hộ của các nghiên cứu trước, như nghiên cứu của Tran (2010), Ha và Nguyen (2014).

(iii) Lục lựng lao động $(L)$ : Theo Thông tư của Bộ trưởng Bộ Kế hoạch và Đầu tư số 02/2012/TT-BKHĐT ngày 10 tháng 01 năm 2012, lực lượng lao động (đơn vị tính nghìn người) 
được sử dụng trong nghiên cứu bao gồm những người từ 15 tuổi trở lên có việc làm (đang làm việc) và những người thất nghiệp trong thời kỳ tham chiếu (7 ngày trước thời điểm quan sát). Thước đo này được sử dụng trong các nghiên cứu của Tran (2010), Ha và Nguyen (2014).

(iv) Tốc độ tăng năng suất nhân tố tổng hợ: Trong nghiên cứu này, chúng tôi sử dụng công thức tính tốc độ tăng năng suất nhân tố tổng hợp; xác định tỷ phần đóng góp của vốn, lao động và TFP trong tăng trưởng GDP của vùng theo phương pháp hạch toán, gắn liền với giả định hiệu quả theo quy mô không đổi do Tổ chức Năng suất châu Á hướng dẫn đưa vào áp dụng (Tang, 2018).

\section{Kết quả và thảo luận}

\subsection{Kết quả sản xuất và tốc độ tăng trưởng của vùng KTT円 phía Nam}

Trong hơn 20 năm qua (1998 - 2018), kể từ khi Chính phủ ký Quyết định phê duyệt Quy hoạch tổng thể phát triển kinh tế - xã hội của các vùng KTTĐ, cùng với việc thực hiện những chính sách cải cách kinh tế toàn diện với nội dung cốt lõi là sự kết hợp của tự do hóa, ổn định hóa, thay đổi thể chế, cải cách cơ cấu và tăng cường mở rộng quan hệ hợp tác quốc tế, vùng KTTĐ phía Nam đã có bước phát triển vượt bậc cả về tốc độ tăng trưởng kinh tế, xây dựng cơ sở vật chất kỹ thuật và chuyển dịch cơ cấu kinh tế, cụ thể:

\section{Thứ nhất, tổng sản phẩm của vùng KTTĐ phía Nam (GDP vùng).}

Trong những năm gần đây, tăng trưởng GDP của vùng vào loại cao nhất trong cả nước. Tuy nhiên, quy mô kinh tế của vùng còn nhỏ, nên dù tốc độ tăng trưởng kinh tế cao nhưng thực lực kinh tế của vùng chưa mạnh và còn hạn chế.

\section{Bảng 1}

Tốc độ tăng trưởng GDP của vùng KTTĐ phía Nam

Năm GDP vùng (tỷ đồng) Tốc độ tăng trưởng GDP vùng (\%)

\begin{tabular}{lll}
\hline 2013 & $1,320,539$ & 10.78 \\
2014 & $1,418,223$ & 7.40 \\
2015 & $1,491,120$ & 5.14 \\
2016 & $1,594,347$ & 6.92 \\
2017 & $1,693,272$ & 6.20 \\
\hline
\end{tabular}

Nguồn: Tính toán từ số liệu Niên giám thống kê của các tỉnh, thành phố vùng KTTĐ phía Nam 


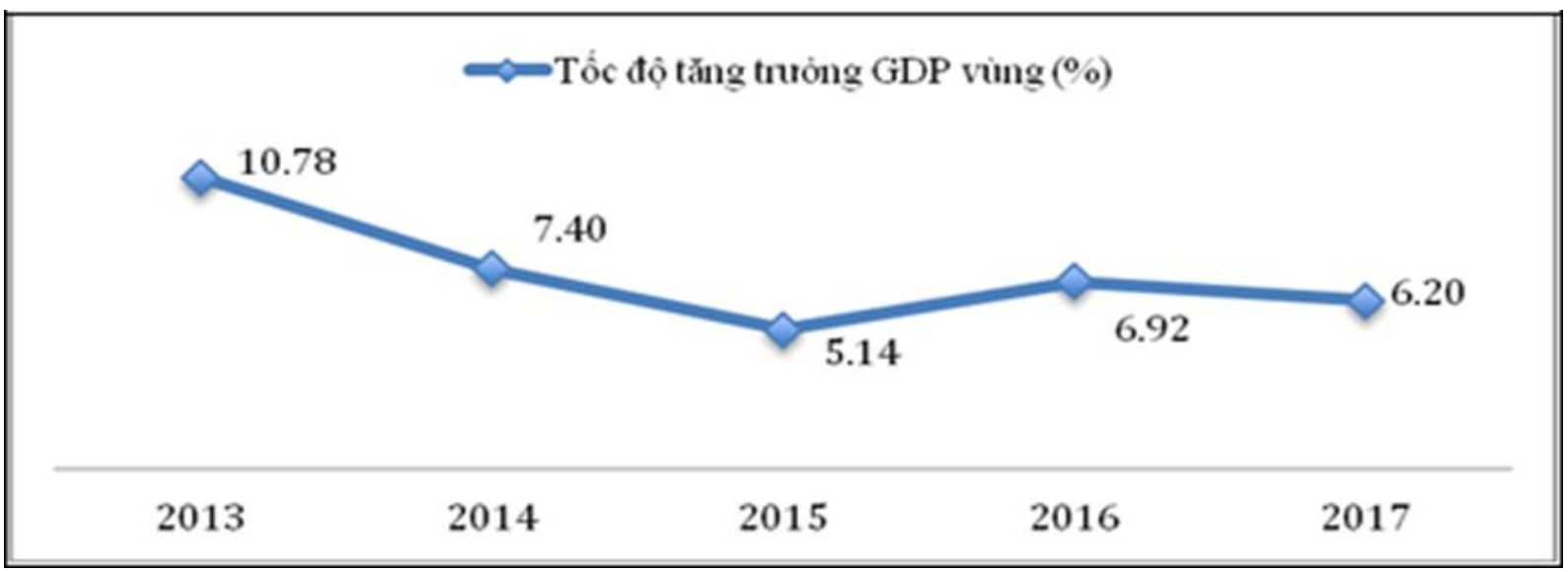

Hình 1. Tốc độ tăng trưởng GDP vùng KTTĐ phía Nam

Nguồn: Tính toán từ số liệu Niên giám thống kê của các tỉnh, thành phố vùng KTTĐ phía Nam

Qua Bảng 1 cho thấy, GDP vùng theo giá so sánh 2010 tăng hàng năm. Điều đó đã phần nào thể hiện được tính động lực của vùng KTTĐ phía Nam so với cả nước. Tuy nhiên tốc độ tăng trưởng GDP của vùng có sự thay đổi đáng kể, cụ thể năm 2013 từ 10,78\% giảm xuống còn 6,20\% năm 2017, khi so sánh các mục tiêu quy hoạch giai đoạn 2011 - 2020 với tiềm năng thì sự tăng trưởng kinh tế chưa đạt so với mục tiêu quy hoạch đã được phê duyệt là tốc độ tăng trưởng bình quân của vùng đạt $11,5 \%$. Nguyên nhân tốc độ tăng trưởng của vùng sụt giảm là do các ngành công nghiệp, trong đó có ngành khai khoáng; dịch vụ và xuất nhập khẩu sau một thời gian tăng nhanh đã chững lại và tăng chậm hơn nhịp độ tăng trưởng chung của GDP, làm ảnh hưởng không ít đến sự phát triển chung của cả vùng.

\section{Thứ hai, GDP bình quân đầu người của vùng KTTĐ phía Nam.}

So với cả nước và các vùng KTTĐ khác của cả nước thì thu nhập bình quân đầu người của vùng KTTĐ phía Nam là cao nhất, cụ thể thu nhập bình quân đầu người của cả nước năm 2010 là 1.273 USD, năm 2017 là 2.389 USD; thu nhập này tương ứng với vùng KTTĐ Bắc Bộ cũng chỉ là 1.699 USD và 3.481 USD. Tuy nhiên, thu nhập bình quân đầu người của vùng KTTĐ phía Nam còn thấp và có sự chênh lệch khá lớn giữa các tỉnh, thành phố của vùng. Năm 2017, GDP bình quân đầu người của thành phố HCM là 5.974 USD, tỉnh Bình Dương là 5.261 USD, Đồng Nai là 4.119 USD, BRVT là 10.958 USD, trong khi đó các tỉnh còn lại của vùng có GDP bình quân đầu người còn khá thấp như: tỉnh Bình Phước là 2.366 USD, Tây Ninh là 2.536 USD, Long An là 2.693 USD và Tiền Giang là 1.918 USD.

\section{Bảng 2}

Thu nhập bình quân đầu người một năm theo giá hiện hành phân theo vùng ( $Đ V T$ : USD)

\begin{tabular}{lccccc}
\hline \multicolumn{1}{c}{ Vùng } & $\mathbf{2 0 1 0}$ & $\mathbf{2 0 1 2}$ & $\mathbf{2 0 1 4}$ & $\mathbf{2 0 1 6}$ & $\mathbf{2 0 1 7}$ \\
\hline Cả nước & $\mathbf{1 , 2 7 3}$ & $\mathbf{1 , 7 4 8}$ & $\mathbf{2 , 0 5 2}$ & $\mathbf{2 , 2 1 5}$ & $\mathbf{2 , 3 8 9}$ \\
Vùng KTTĐ Bắc Bộ & $\mathbf{1 , 6 9 9}$ & $\mathbf{2 , 1 4 0}$ & $\mathbf{2 , 4 0 9}$ & $\mathbf{3 , 0 6 1}$ & $\mathbf{3 , 4 8 1}$ \\
Vùng KTTĐ miền Trung & $\mathbf{1 , 1 5 2}$ & $\mathbf{1 , 2 0 1}$ & $\mathbf{1 , 4 0 2}$ & $\mathbf{1 , 8 9 6}$ & $\mathbf{2 , 4 6 7}$ \\
Vùng KTTĐ ĐBSCL & $\mathbf{1 , 1 0 7}$ & $\mathbf{1 , 2 5 3}$ & $\mathbf{1 , 5 4 0}$ & $\mathbf{1 , 7 4 2}$ & $\mathbf{2 , 3 0 1}$ \\
\hline
\end{tabular}




\begin{tabular}{lccccc}
\hline \multicolumn{1}{c}{ Vùng } & $\mathbf{2 0 1 0}$ & $\mathbf{2 0 1 2}$ & $\mathbf{2 0 1 4}$ & $\mathbf{2 0 1 6}$ & $\mathbf{2 0 1 7}$ \\
\hline Vùng KTTĐ phía Nam. Trong đó: & $\mathbf{2 , 8 5 6}$ & $\mathbf{3 , 2 5 1}$ & $\mathbf{4 , 5 5 8}$ & $\mathbf{4 , 6 8 6}$ & $\mathbf{4 , 9 2 7}$ \\
TP HCM & 3,309 & 4,164 & 4,986 & 5,714 & 5,974 \\
Bình Dương & 3,105 & 3,747 & 4,388 & 4,805 & 5,261 \\
Đồng Nai & 2,697 & 2,916 & 3,355 & 3,909 & 4,119 \\
BRVT & 7,413 & 7,932 & 9,462 & 9,562 & 10,958 \\
Bình Phước & 1,664 & 1,836 & 2,086 & 2,158 & 2,366 \\
Tây Ninh & 1,670 & 1,768 & 2,144 & 2,291 & 2,536 \\
Long An & 1,895 & 2,143 & 2,220 & 2,545 & 2,693 \\
Tiền Giang & 1,096 & 1,507 & 1,636 & 1,721 & 1,918 \\
\hline
\end{tabular}

Nguồn: Tổng cục Thống kê và Niên giám thống kê của các tỉnh, thành phố vùng KTTĐ phía Nam

Thứ ba, cơ cấu kinh tế và cơ cấu ngành.

(i) Cơ cấu ngành kinh tế nhìn ở phía tổng cung

Vùng KTTĐ phía Nam đạt được mức tăng trưởng kinh tế nhanh trong thời gian qua là kết quả của những thay đổi quan trọng trong cơ cấu nền kinh tế của vùng. Cơ cấu kinh tế của vùng đã chuyển dịch theo hướng tăng dần tỷ trọng khu vực công nghiệp, xây dựng và dịch vụ, giảm dần của khu vực nông, lâm nghiệp và thuỷ sản. Từ một vùng có nền công nghiệp chưa phát triển, đến nay vùng KTTĐ phía Nam đang từng bước xây dựng một nền công nghiệp theo hướng hiện đại.

\section{Bảng 3}

Cơ cấu tổng sản phẩm theo giá hiện hành của vùng KTTĐ phía Nam phân theo khu vực kinh tế (ĐVT: \%)

\begin{tabular}{lcccc}
\hline \multicolumn{1}{c}{ Phân theo khu vực kinh tế } & $\mathbf{2 0 1 4}$ & $\mathbf{2 0 1 5}$ & $\mathbf{2 0 1 6}$ & $\mathbf{2 0 1 7}$ \\
\hline Tổng số & $\mathbf{1 0 0 . 0 0}$ & $\mathbf{1 0 0 . 0 0}$ & $\mathbf{1 0 0 . 0 0}$ & $\mathbf{1 0 0 . 0 0}$ \\
Nông, lâm nghiệp và thuỷ sản & 5.99 & 6.18 & 6.40 & 5.86 \\
Công nghiệp và xây dựng & 47.93 & 44.16 & 39.41 & 40.43 \\
Dịch vụ & 36.15 & 38.03 & 43.05 & 42.79 \\
Thuế sản phẩm trừ trợ cấp sản phẩm & 9.93 & 11.64 & 11.13 & 10.92 \\
\hline
\end{tabular}

Nguồn: Tính toán từ số liệu Niên giám thống kê của các tỉnh, thành phố vùng KTTĐ phía Nam

Qua Bảng 3 cho thấy, tỷ trọng ngành nông, lâm nghiệp và thuỷ sản giảm nhẹ, từ 5,99\% năm 2014 xuống còn 5,86\% năm 2017; tỷ trọng đóng góp của ngành công nghiệp và xây dựng giảm, từ 47,93\% năm 2014 xuống còn 40,43\% năm 2017; sự thay đổi giảm của các ngành nông, lâm nghiệp, thuỷ sản, công nghiệp và xây dựng thay vào đó là tỷ trọng đóng góp của ngành dịch vụ tăng lên cao, từ 36,15\% năm 2014 lên 43,05\% năm 2016, nhưng sau đó giảm nhẹ còn $42,79 \%$ năm 2017. 
Tốc độ tăng trưởng của các ngành kinh tế cũng liên tục thay đổi trong các năm. Cụ thể, ngành nông, lâm nghiệp và thuỷ sản giảm đáng kể từ $5,81 \%$ năm 2013 giảm xuống còn $3,27 \%$ năm 2017, mặc dù trong các năm 2014 và đặc biệt là trong năm 2016 có sự gia tăng đáng kể lên $8,64 \%$; ngành công nghiệp và xây dựng từ $6,16 \%$ năm 2013 giảm xuống còn $5,12 \%$, thậm chí mức tăng trưởng giảm thấp nhất ở năm 2015 chỉ còn $1,89 \%$, điều này cũng cho thấy trong năm 2015 tổng sản phẩm của ngành khai khoáng giảm nguyên nhân chủ yếu là do giá dầu thế giới giảm; riêng trong ngành dịch vụ tuy tốc độ tăng trưởng có sự sụt giảm nhẹ nhưng tốc độ tăng trưởng hàng năm khá cao như năm 2017 đạt $8,01 \%$ và đặc biệt trong năm 2014 đạt 9,01\%.

\section{Bảng 4}

Tốc độ tăng trưởng GDP theo giá so sánh 2010 phân theo khu vực kinh tế của vùng KTTĐ phía Nam (ĐVT: \%)

\begin{tabular}{lrrrrr}
\hline \multicolumn{1}{c}{ Năm } & $\mathbf{2 0 1 3}$ & $\mathbf{2 0 1 4}$ & $\mathbf{2 0 1 5}$ & $\mathbf{2 0 1 6}$ & $\mathbf{2 0 1 7}$ \\
\hline GDP & 10.78 & 7.40 & 5.14 & 6.92 & 6.20 \\
Nông, lâm nghiệp và thuỷ sản & 5.81 & 6.27 & 5.71 & 8.64 & 3.27 \\
Công nghiệp và xây dựng & 6.16 & 5.95 & 1.89 & 4.81 & 5.12 \\
Dịch vụ & 8.88 & 9.01 & 7.27 & 8.57 & 8.01 \\
Thuế sản phẩm trừ trợ cấp sản phẩm & 8.42 & 8.47 & 10.74 & 8.47 & 5.53 \\
\hline
\end{tabular}

Nguồn: Tính toán từ số liệu Niên giám thống kê của các tỉnh, thành phố vùng KTTĐ phía Nam

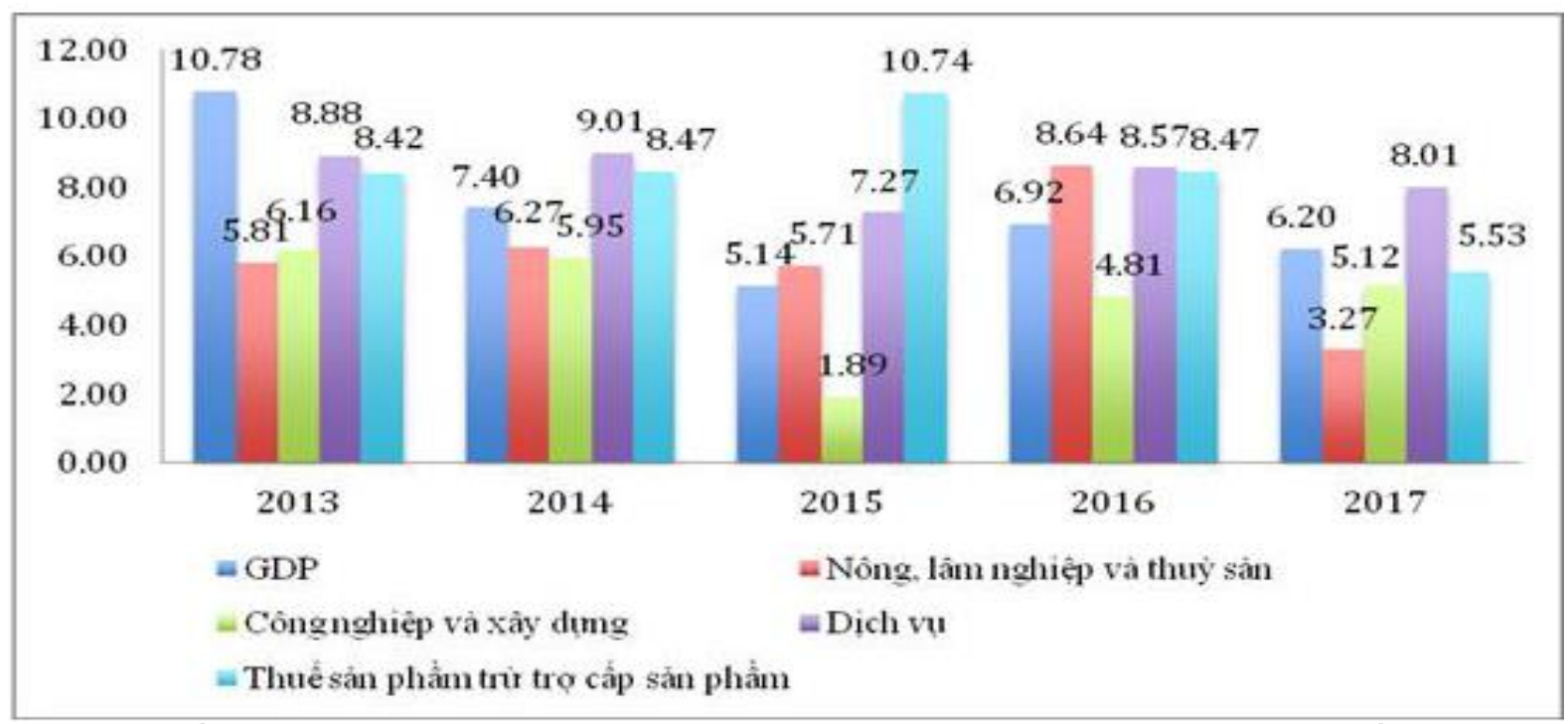

Hình 2. Tốc độ tăng trưởng GDP theo giá so sánh 2010 phân theo khu vực kinh tế của vùng KTTÐ phía Nam $Đ V T: \%$

Nguồn: Tính toán từ số liệu Niên giám thống kê của các tỉnh, thành phố vùng KTTĐ phía Nam

Về cơ cấu ngành, vùng KTTĐPN đã đạt được mức tăng trưởng cao, nhưng bản thân quá trình tăng trưởng vẫn thể hiện chất lương tăng truơong còn thấp. Với cơ cấu ngành nông, lâm 
nghiệp và thuỷ sản chỉ đạt 5,86\%; ngành công nghiệp và xây dựng là 40,43\%; ngành dịch vụ năm 2017 là 42,79\%, tỷ trọng các ngành trong cơ cấu kinh tế của vùng vẫn chưa thể đạt đến mức là một vùng có nền kinh tế phát triển mà vùng mới đang tiệm cận dần đến các chỉ tiêu cơ cấu ngành kinh tế cơ bản cần đạt được của một nền kinh tế phát triển.

Chất lượng tăng trưởng thấp còn thể hiện ngay trong cơ cấu của từng ngành. Tốc độ chuyển dịch cơ cấu nông, lâm nghiệp và thuỷ sản còn chậm, tuy tỷ trọng giá trị sản xuất nông nghiệp có giảm nhưng vẫn chiếm tỷ trọng còn cao, tỷ trọng giá trị ngành chăn nuôi, ngành thủy sản vẫn còn thấp; tỷ trọng ngành công nghiệp còn thấp và phụ thuộc vào ngành khai khoáng nhiều. Những cạnh tranh, những đe dọa của thiên tai bất thường, những khó khăn về giới hạn năng lực sản xuất và diện tích canh tác đối với ngành thủy sản cũng khiến cho ngành này đang phải đứng trước nguy cơ tỷ trọng sẽ giảm trong thời gian tới.

Tăng nhanh tỷ trọng giá trị dịch vụ là xu thế chủ đạo trong chuyển dịch cơ cấu kinh tế của các nước phát triển, phù hợp với sự phát triển nhanh chóng của tiến bộ công nghệ và phát triển nền kinh tế tri thức. Tỷ trọng giá trị dịch vụ trong cơ cấu ngành kinh tế tăng với tốc độ chậm. Điểm yếu của khu vực dịch vụ vùng KTTĐ phía Nam chính là cơ cấu ngành dịch vụ và tỷ trọng các phân ngành còn có sự chênh lệch lớn. Các ngành dịch vụ cơ bản như: khách sạn, nhà hàng, vận tải, kho bãi, thông tin liên lạc... có tác dụng thúc đẩy sự phát triển của các phân ngành dịch vụ khác lại gần như không có sự tăng trưởng. Trong 5 năm từ năm 2013 đến 2017 , tỷ trọng của các ngành dịch vụ cơ bản chỉ chiếm dao động khoảng 48\%, phân ngành khách sạn, nhà hàng trong nhiều năm vẫn giữ ở mức $8,5 \%$, trong khi đó phân ngành thương nghiệp và sửa chữa vật phẩm tiêu dùng tăng nhanh và chiếm tỷ trọng cao $45 \%$. Ngành vận tải và thông tin liên lạc là hai ngành tác động trực tiếp và không thể thiếu đối với các ngành sản xuất cũng chỉ chiếm một tỷ là 9,8\% năm 2013 và tăng lên 10,2\% trong năm 2017. Các dịch vụ cao cấp như ngân hàng, tài chính, chuyển giao công nghệ năng lực cạnh tranh vẫn còn thấp.

(ii) Co cấu kinh tế nhìn tù̀ góc độ tổng cầu Nhìn nhận từ phía tổng cầu, mức tăng trưởng cao mà vùng KTTĐ phía Nam đạt được trong thời gian qua là do tỷ lệ tiêu dùng đã giảm, tiết kiệm nội địa tăng dẫn đến đầu tư trong nước tăng lên.

Vùng KTTĐ phía Nam tuân theo quy luật phát triển chung của nền kinh tế. Theo đó, tỷ lệ tiêu dùng trong GDP giảm dần và thường giảm nhanh trong giai đoạn đầu của sự phát triển, tiết kiệm dành cho tích lũy đầu tư sẽ tăng lên. Tỷ lệ tiêu dùng của vùng từ trên $70 \%$ năm 2010 , giảm xuống còn $60,3 \%$ GDP vào năm 2015 ; tỷ lệ tiết kiệm nội địa đã tăng lên từ $29,8 \%$ năm 2010, lên 39,7\% năm 2015; tỷ lệ đầu tư tích lũy tài sản trong GDP tăng từ 40,6\% năm 2010, lên trên $47 \%$ năm 2015 . Tuy nhiên, tốc độ giảm tỷ lệ tiêu dùng của vùng còn chậm, trung bình dịch chuyển là $1,9 \%$ hàng năm.

Vùng KTTĐ phía Nam đóng góp giá trị xuất khẩu khá lớn trong tổng giá trị xuất khẩu của cả nước hàng năm từ năm 2013 đến năm 2017, điều này góp phần làm cho tốc độ tăng trưởng GDP đang ngày cao và càng gia tăng. Vùng KTTĐ phía Nam trở thành vùng KTTĐ có giá trị kim ngạch xuất khẩu hàng hoá lớn nhất của cả nước. 


\section{Bảng 5}

Xuất nhập khẩu hàng hóa của vùng KTTĐ phía Nam và cả nước

\begin{tabular}{|c|c|c|c|c|c|c|}
\hline \multicolumn{2}{|c|}{ Chỉ tiêu } & 2013 & 2014 & 2015 & 2016 & 2017 \\
\hline & Xuất khẩu & $132,032.900$ & $150,217.100$ & $162,016.700$ & $176,580.800$ & $214,019.100$ \\
\hline $\begin{array}{l}\text { Cả nước } \\
\text { (triêu }\end{array}$ & $\begin{array}{l}\text { Nhập khẩu } \\
\text { Cán cân }\end{array}$ & $132,032.600$ & $147,849.100$ & $165,775.900$ & $174,978.400$ & $211,103.700$ \\
\hline USD) & $\begin{array}{l}\text { thương } \\
\text { mại }\end{array}$ & 0.300 & $2,368.000$ & $-3,759.200$ & $1,602.400$ & $2,915.400$ \\
\hline Vùng & Xuất khẩu & $68,548.636$ & $77,980.032$ & $79,022.433$ & $86,250.352$ & $97,511.571$ \\
\hline КТTÐ & Nhập khẩu & $55,840.456$ & $61,951.549$ & $70,652.160$ & $78,781.017$ & $91,427.550$ \\
\hline $\begin{array}{l}\text { phía Nam } \\
\text { (triệu } \\
\text { USD) }\end{array}$ & $\begin{array}{l}\text { Cán cân } \\
\text { thương } \\
\text { mại }\end{array}$ & $12,708.180$ & $16,028.483$ & $8,370.273$ & $7,469.335$ & $6,084.021$ \\
\hline $\begin{array}{l}\text { Tốc độ tăng } \\
\text { xuất khẩu ( }\end{array}$ & $\begin{array}{l}\text { trưởng của } \\
\text { b) }\end{array}$ & 3.94 & 13.76 & 1.34 & 9.15 & 13.06 \\
\hline $\begin{array}{l}\text { Tốc độ tăng } \\
\text { nhập khẩu }\end{array}$ & $\begin{array}{l}\text { trưởng của } \\
\text { \%) }\end{array}$ & 14.11 & 10.94 & 14.04 & 11.51 & 16.05 \\
\hline $\begin{array}{l}\text { Tỷ trọng xu } \\
\text { vùng KTTE } \\
\text { cả nước (\% }\end{array}$ & $\begin{array}{l}\text { phẩu của } \\
\text { phíam/ }\end{array}$ & 51.92 & 51.91 & 48.77 & 48.84 & 45.56 \\
\hline $\begin{array}{l}\text { Tỷ trọng nh } \\
\text { vùng KTTE } \\
\text { cả nước }(\%\end{array}$ & $\begin{array}{l}\text { p khẩu của } \\
\text { phía Nam/ }\end{array}$ & 42.29 & 41.90 & 42.62 & 45.02 & 43.31 \\
\hline
\end{tabular}

Nguồn: Tính toán từ số liệu Tổng cục Thống kê và NGTK của các tỉnh, thành phố vùng KTTĐ phía Nam

Mặc dù tỷ trọng xuất khẩu của vùng so với cả nước giảm từ năm 2013 đến năm 2017 , nhưng tốc độ tăng trưởng của xuất khẩu ngày càng cao và càng gia tăng, do đó vùng KTTĐ phía Nam thặng dư thương mại từ năm 2013 là 12.708,180 triệu USD, tăng lên 16.028,483 triệu USD, nhưng sau đó giảm dần đến năm 2017, chỉ còn thặng dư thương mại là 6.084,021 triệu USD. Điều này cho thấy tốc độ tăng trưởng của nhập khẩu có xu hướng cao hơn nhiều so với tốc độ tăng của xuất khẩu, thể hiện qua các năm từ năm 2015 đến năm 2017. Xu hướng này không hoàn toàn có ý nghĩa tiêu cực, đây cũng là xu thế tất yếu của Việt Nam nói chung và vùng KTTĐ phía Nam nói riêng đang trong giai đoạn đầu tiến hành công nghiệp hóa, hiện đại hóa cần nhập nhiều thiết bị, công nghệ máy móc nhằm nâng cao trình độ kỹ thuật cho sản xuất trong nước. Song bên cạnh đó, sự chênh lệch quá lớn về giá trị xuất nhập khẩu của các tỉnh, thành phố và cơ cấu xuất nhập khẩu của vùng vẫn còn nhiều tồn tại gây hạn chế khả năng đóng góp của xuất, nhập khẩu vào tăng trưởng kinh tế của vùng KTTĐ phía Nam cũng như của cả nước là điều cần quan tâm hơn nữa. Nguyên nhân là do: (i) mặc dù xuất khẩu đã tăng trưởng rất nhanh từ năm 2013 đến 2017, nhưng cơ cấu xuất khẩu lại hầu như không có nhiều thay đổi, chỉ thiên về xuất khẩu nông sản chưa chế biến như lúa gạo, cà phê, thủy sản và khoáng sản chủ yếu là dầu thô, những mặt hàng có hàm lượng công nghệ, chất lượng cao xuất khẩu còn ít. Tỷ trọng hàng hóa công nghệ cao xuất khẩu trên tổng giá trị chế biến hàng xuất khẩu của vùng còn thấp; (ii) mạng lưới các ngành công nghiệp phụ trợ phục vụ trực tiếp cho các hoạt động sản xuất để xuất khẩu của vùng hiện nay chưa phát triển. Ngành sản xuất xuất khẩu của vùng chủ 
yếu là nhập khẩu nguyên liệu để gia công như ngành da giày, may mặc...; tỷ trọng hàng nhập khẩu phục vụ cho tiêu dùng và nguyên vật liệu trong cơ cấu hàng nhập khẩu tuy đã giảm nhưng chiếm tỷ trọng lớn; tỷ trọng nhập khẩu máy móc, thiết bị, công nghệ còn thấp.

\section{Thú tư, lạm phát.}

Từ năm 2013 đến năm 2017, kinh tế Việt Nam nói chung và vùng KTTĐ phía Nam nói riêng có sự thay đổi đáng kể về tăng trưởng kinh tế, do đó lạm phát cũng thay đổi. Cụ thể, trong năm 2013, tốc độ tăng trưởng GDP vùng tăng cao là 10,78\% thì lạm phát cũng tăng lên ở mức cao là $6,60 \%$, nhưng đến năm 2015 , khi tốc độ tăng trưởng kinh tế của vùng thấp chỉ còn $5,14 \%$ thì tỷ lệ lạm phát tương ứng là $0,63 \%$, sau đó tốc độ tăng trưởng năm 2017 là $6,20 \%$ thì tỷ lệ lạm phát cũng tăng lên $3,53 \%$. Điều này cho thấy, tốc độ tăng trưởng kinh tế hàng năm của vùng luôn cao hơn tỷ lệ lạm phát từ năm 2013 đến năm 2017; khi tốc độ tăng trưởng kinh tế của vùng tăng thì tỷ lệ lạm phát sẽ tăng và ngược lại. Như vậy, tỷ lệ lạm phát phụ thuộc đồng biến tốc độ tăng trưởng kinh tế của vùng.

\section{Bảng 6}

Tốc độ tăng trưởng GDP và tỷ lệ lạm phát của vùng KTTĐ phía Nam

\begin{tabular}{lccccc}
\hline Chỉ tiêu & $\mathbf{2 0 1 3}$ & $\mathbf{2 0 1 4}$ & $\mathbf{2 0 1 5}$ & $\mathbf{2 0 1 6}$ & $\mathbf{2 0 1 7}$ \\
\hline Tăng trưởng GDP $(\%)$ & 10.78 & 7.40 & 5.14 & 6.92 & 6.20 \\
Lạm phát (\%) & 6.60 & 1.84 & 0.63 & 4.74 & 3.53 \\
\hline
\end{tabular}

Nguồn: Tổng cục Thống kê và Niên giám Thống kê các tỉnh, thành phố của vùng KTTĐ phía Nam

\section{2. Đánh giá kinh tế tăng trưởng theo chiều sâu của vùng KTTĐ phía Nam}

Tốc độ tăng trưởng GDP của vùng KTTĐ phía Nam đạt ở mức cao, với mức tăng bình quân hàng năm từ năm 2013 - 2017 là 7,06\%. Từ một vùng kinh tế có nền công nghiệp chưa phát triển, vùng KTTĐ phía Nam ngày nay từng bước xây dựng một nền công nghiệp theo hướng hiện đại. Tuy vậy, vấn đề nổi lên hiện nay đó là vấn đề chất lượng tăng trưởng liên quan đến tỷ trọng đóng góp của TFP còn thấp. Sự tăng trưởng đạt được chủ yếu do tăng vốn đầu tư và số lượng lao động chứ không phải là do nâng cao chất lượng, hiệu quả đầu tư, trình độ công nghệ và chất lượng lao động. Điều này đe doạ tính bền vững trong hiện tại và tương lai, tạo ra mâu thuẫn giữa tốc độ tăng trưởng và chất lượng, hiệu quả tăng trưởng. 


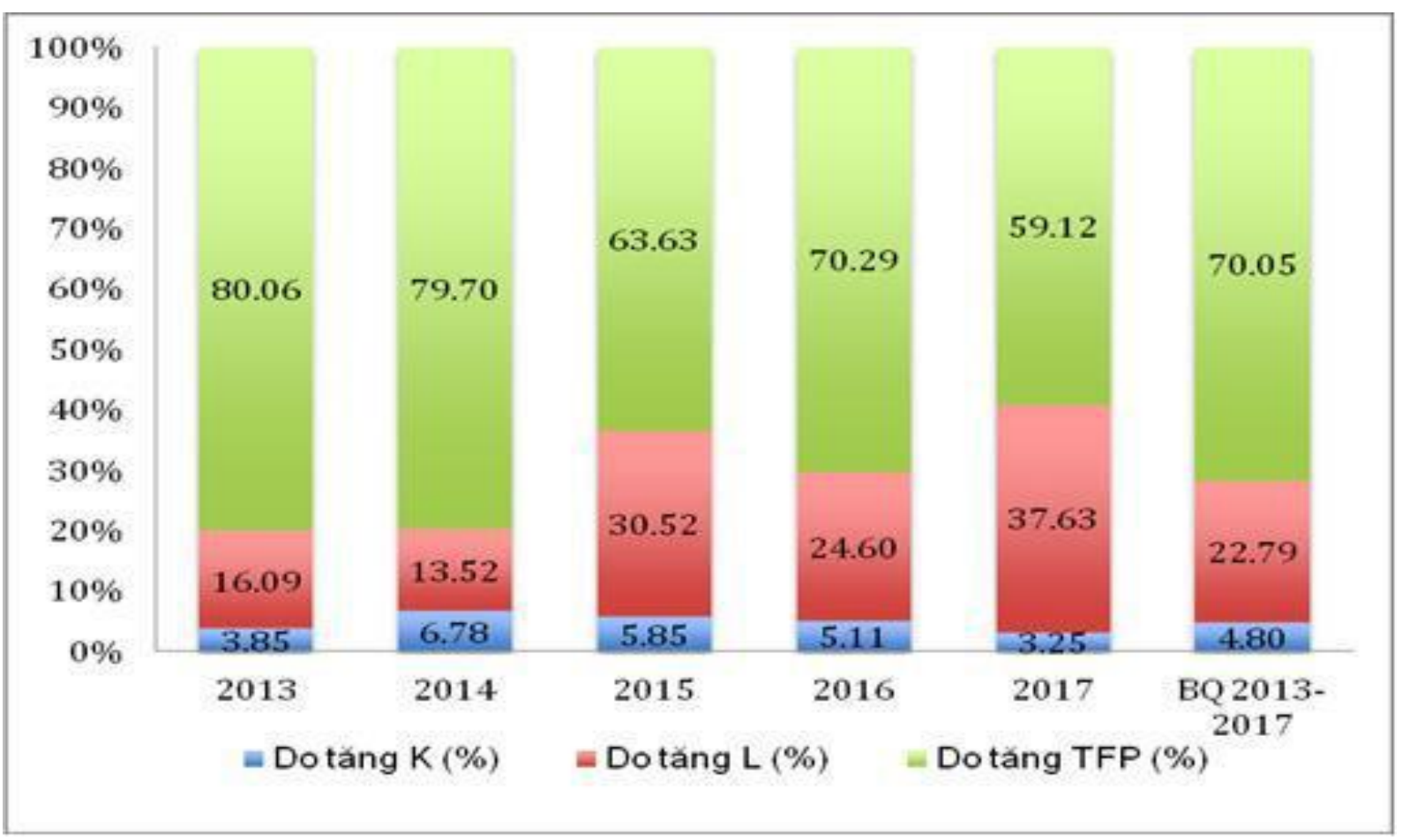

Hình 3. Tỷ phần đóng góp của các nhân tố vào tốc độ tăng GDP của vùng KTTĐ phía Nam

Nguồn: Tính toán từ số liệu Tổng cục Thống kê

Qua Hình 3 cho thấy, từ năm 2013 đến năm 2017, tăng trưởng kinh tế của vùng KTTĐ phía Nam do yếu tố TFP chiếm tỷ trọng khá lớn, đóng góp nhiều nhất vào tăng trưởng kinh tế qua các năm và chiếm 70,05\% bình quân chung cả thời kỳ từ 2013 - 2017, còn vai trò của vốn và lao động chiếm tỷ trọng thấp, tương ứng với tỷ lệ là $4,80 \%$ và $22,79 \%$. Điều đó cũng có nghĩa là tăng GDP của vùng KTTĐ phía Nam từ năm 2013 - 2017 vẫn chủ yếu là do TFP tăng, tức là trong thời gian qua vùng có đầu tư đổi mới công nghệ, hợp lý hoá sản xuất, cải tiến quản lý, nâng cao trình độ của người lao động...

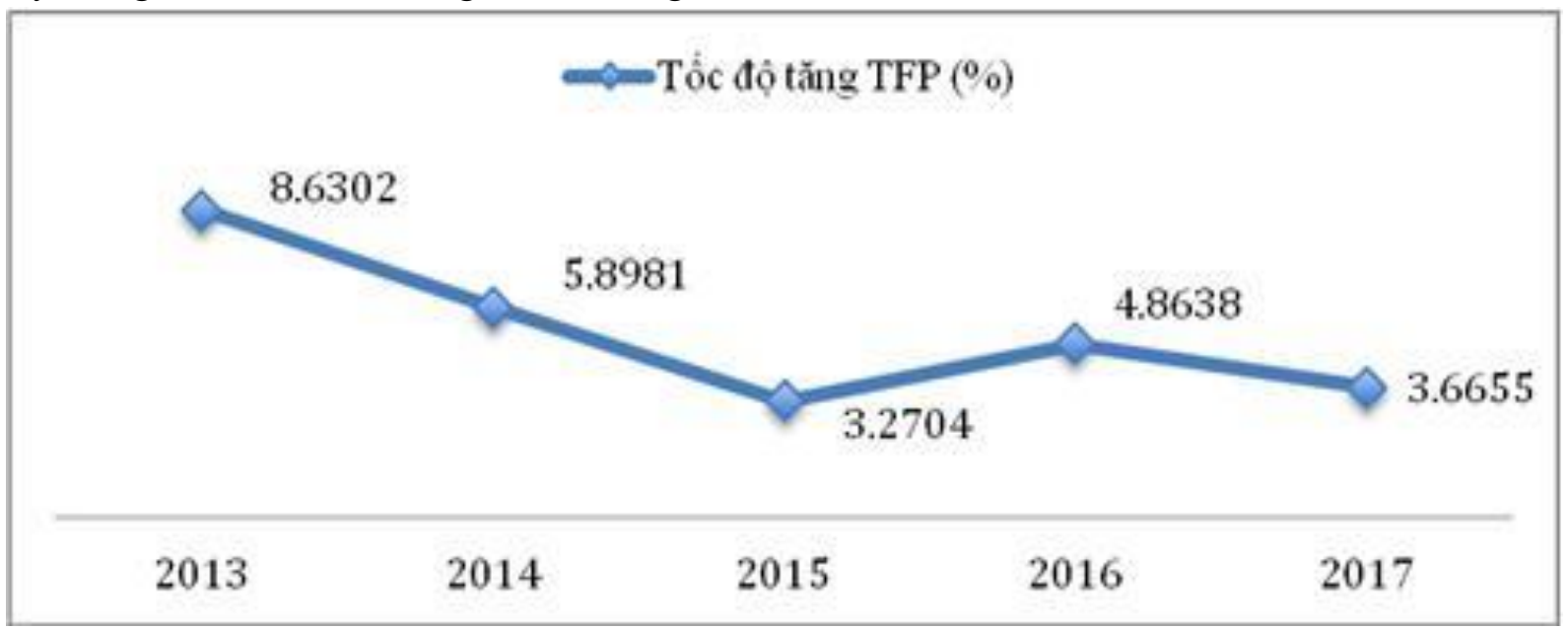

Hình 4. Tốc độ tăng TFP của vùng Kinh tế trọng điểm phía Nam

Nguồn: Tính toán từ số liệu Tổng cục Thống kê 
Từ năm 2013 đến năm 2017, đóng góp của TFP vào GDP có sụt giảm nhiều, cụ thể năm 2013 tỷ trọng đóng góp vào tăng GDP do tăng TFP là 80,06\%, nhưng đến năm 2016 giảm còn 70,29\%, sau đó đến năm 2017 giảm xuống còn 59,12\%; tương tự như TFP, tỷ trọng đóng góp vào tăng GDP do tăng vốn cũng giảm từ 3,85\% năm 2013 tăng lên 5,11 năm 2016, nhưng lại giảm chỉ còn $3,25 \%$ vào năm 2017 . Việc đóng góp của nhân tố TFP và vốn có xu hướng giảm, thì ngược lại đóng góp của nhân tố lao động lại có xu hướng gia tăng từ 16,09\% năm 2013, tăng lên $24,60 \%$ của năm 2016 và sau đó tăng lên đến 37,63\% năm 2017. Các chỉ số này phản ánh tính chất của tăng trưởng kinh tế của vùng đang hướng tới nâng cao chất lượng tăng trưởng và phát triển nghiêng về chiều sâu hơn là chiều rộng nhưng thiếu tính bền vĩng và ổn định. Xu hướng phát triển chủ yếu dựa vào yếu tố TFP, trong khi đó, yếu tố vốn đầu tư thấp, chủ yếu phải đi vay từ nước ngoài, vay trong dân cư... sẽ khiến cho tăng trưởng thiếu tính bền vững, ổn định, dễ bị tác động từ các yếu tố bên ngoài, đặc biệt từ sự biến động của thị trường vốn. Yếu tố lao động được coi là nguồn lực nội sinh, hiện đang có lợi thế so sánh như giá rẻ, dồi dào... đóng vai trò cao hơn nhiều so với yếu tố vốn trong tăng trưởng.

(i) Về hiệu quả đầu tur: Giá trị vốn đầu tư thực hiện của vùng liên tục tăng từ năm 2013 đến năm 2017. Tuy nhiên, hiệu quả đầu tư lại thấp và ngày càng giảm, thể hiện qua ICOR còn khá cao và có xu hướng tăng, cụ thể từ năm 2013, hệ số ICOR của vùng là 2,90, đến năm 2015 tăng cao lên 5,99, nhưng đến năm 2016 giảm xuống còn 4,62, sau đó đến năm 2017 lại tăng lên 5,17 . Tuy nhiên so sánh ICOR vùng so với ICOR theo giá so sánh 2010 của cả nước thì vẫn còn thấp. Điều này cho thấy hiệu quả sử dụng vốn đầu tư thực hiện của vùng KTTĐ phía Nam tốt hơn so với cả nước.

\section{Bảng 7}

Vốn đầu tư, GDP theo giá so sánh 2010, tốc độ tăng vốn đầu tư, GDP và hệ số hiệu quả vốn đầu tư (ICOR) của vùng KTTĐ phía Nam

\begin{tabular}{lccccc}
\hline \multicolumn{1}{c}{ Chỉ tiêu } & $\mathbf{2 0 1 3}$ & $\mathbf{2 0 1 4}$ & $\mathbf{2 0 1 5}$ & $\mathbf{2 0 1 6}$ & $\mathbf{2 0 1 7}$ \\
\hline $\begin{array}{l}\text { Vốn đầu tư theo giá so sánh 2010 } \\
\text { (tỷ đồng) }\end{array}$ & 373,277 & 398,671 & 436,555 & 476,934 & 511,387 \\
$\begin{array}{l}\text { GDP theo giá so sánh } 2010 \\
\text { (tỷ đồng) }\end{array}$ & $1,320,539$ & $1,418,223$ & $1,491,120$ & $1,594,347$ & $1,693,272$ \\
Mức tăng GDP (tỷ đồng) & 128,549 & 97,684 & 72,897 & 103,227 & 98,925 \\
Tốc độ tăng vốn đầu tư (\%) & 3.35 & 6.80 & 9.50 & 9.25 & 7.22 \\
Tốc độ tăng GDP (\%) & 10.78 & 7.40 & 5.14 & 6.92 & 6.20 \\
Tỷ trọng vốn đầu tư/ GDP (\%) & 28.27 & 28.11 & 29.28 & 29.91 & 30.20 \\
Hệ số hiệu quả vốn đầu tư ICOR & $\mathbf{2 . 9 0}$ & $\mathbf{4 . 0 8}$ & $\mathbf{5 . 9 9}$ & $\mathbf{4 . 6 2}$ & $\mathbf{5 . 1 7}$ \\
\hline
\end{tabular}

Nguồn: Tính toán từ số liệu Niên giám thống kê các tỉnh, thành phố vùng KTTĐ phía Nam

Có thể nói trong những năm qua, nhờ đổi mới cơ chế, vùng KTTĐ phía Nam đã huy động được tài sản cố định và khai thác hiệu quả các công suất đã đầu tư trước đây, do vậy kết quả đầu tư tương đối có hiệu quả so với cả nước, ICOR thấp. Tuy nhiên, cùng với chính sách 
kích cầu, đầu tư vào kết cấu cơ sở hạ tầng tăng nhanh, ICOR đã tăng nhanh ở các năm 2016 và 2017 và có xu hướng tăng ở những năm sau. Có nhiều nguyên nhân dẫn đến tình trạng đầu tư kém hiệu quả, ICOR cao, đó là:

Một là, ICOR tăng một phần là vì vùng KTTĐ phía Nam đang trong thời kỳ của quá trình công nghiệp hóa, hiện đại hóa, cần phải đầu tư nhiều vào các công trình xây dựng cơ bản, xây dựng cơ sở hạ tầng, là những dự án đòi hỏi số vốn đầu tư cao nhưng lại chậm thu hồi vốn, nhất là các công trình lớn và nhiều năm nữa mới đi vào hoạt động.

Hai là, sự bất hợp lý trong cơ cấu vốn đầu tư, cụ thể vùng quá chú trọng vào những ngành công nghiệp được xếp vào nhóm có sức cạnh tranh thấp, thu hồi vốn chậm (sắt, thép, phân bón, giấy...); đầu tư vào các dự án cần nhiều vốn nhưng sử dụng ít lao động; đầu tư dàn trải.

Ba là, hiệu quả vốn đầu tư của khu vực Nhà nước còn rất thấp nhưng hiệu quả đầu tư ở khu vực này rất thấp. Theo đánh giá của Ngân hàng Thế giới, ICOR trong khu vực Nhà nước là 7,2 trong khi đó ở khu vực tư nhân là 3,8 .

Bốn là, công tác giám sát đầu tư còn hạn chế. Hầu hết các khâu từ quy hoạch, thiết kế, dự toán, đấu thầu, thi công đến giám sát thi công đều chưa tốt dẫn đến không bảo đảm chất lượng công trình. Đồng thời, làm gia tăng thất thoát, lãng phí trong đầu tư xây dựng cơ bản, nhất là vốn đầu tư từ ngân sách nhà nước và nguồn vốn $\mathrm{ODA}$. Vấn đề tham nhũng cũng là một trong những vấn đề gay gắt hiện nay làm giảm hiệu quả đầu tư của nền kinh tế.

(ii) Vì̀ năng suất lao động: Một trong những nguyên nhân giải thích tại sao tỷ trọng cũng như tốc độ tăng TFP của vùng KTTĐ phía Nam trong những năm gần đây lại giảm như vậy xuất phát từ vấn đề năng suất lao động.

\section{Bảng 8}

Mức năng suất lao động và tỷ lệ tăng GDP của vùng KTTĐ phía Nam do tăng năng suất lao động (NSLĐ)

\begin{tabular}{cccccc}
\hline Năm & $\begin{array}{c}\text { GDP giá so sánh } \\
\text { 2010 } \\
\text { (tỷ đồng) }\end{array}$ & $\begin{array}{c}\text { Lao động } \\
\text { (người) }\end{array}$ & $\begin{array}{c}\text { NSLĐ (triệu } \\
\text { đồng/người) }\end{array}$ & $\begin{array}{c}\text { Tỷ lệ tăng GDP do } \\
\text { tăng NSLĐ (\%) }\end{array}$ & $\begin{array}{c}\text { Tốc độ tăng } \\
\text { NSLĐ (\%) }\end{array}$ \\
\hline 2013 & $1,320,539.0$ & $10,974,928$ & 120.323250 & 8.8006 & 8.63 \\
2014 & $1,418,223.0$ & $11,093,131$ & 127.846953 & 6.3203 & 6.25 \\
2015 & $1,491,120.0$ & $11,272,860$ & 132.275217 & 3.5198 & 3.46 \\
2016 & $1,594,347.0$ & $11,472,803$ & 138.967522 & 5.1491 & 5.06 \\
2017 & $1,693,272.0$ & $11,747,909$ & 144.133905 & 3.8068 & 3.72 \\
\hline
\end{tabular}

Nguồn: Tính toán từ số liệu Niên giám thống kê các tỉnh, thành phố của vùng KTTĐ phía Nam

Qua số liệu tính toán ở Bảng 8 cho thấy, năng suất lao động của vùng tăng liên tục hàng năm từ năm 2013 đến năm 2017, tuy nhiên tốc độ tăng NSLĐ của vùng tăng rất chậm và lại có xu hướng giảm từ $8,63 \%$ năm 2013, giảm xuống 5,06\% năm 2016 và sau đó giảm xuống còn 
3,72\% của năm 2017. Từ năm 2013 đến năm 2017, tốc độ tăng NSLĐ bình quân chỉ đạt $5,12 \% /$ năm. Như vậy, rõ ràng đóng góp NSLĐ trong thời gian vừa qua, chẳng những không tăng lên nhiều so với các nước khu vực chúng ta lại càng bị cách xa thêm nữa.

\section{Bảng 9}

Tính toán tốc độ tăng TFP theo phương pháp bình quân của vùng KTTĐ phía Nam

\begin{tabular}{cccccccc}
\hline Năm & $\begin{array}{c}\text { Tỷ lệ tăng } \\
\text { GDP do } \\
\text { tăng NS vốn } \\
\text { đầu tư (\%) }\end{array}$ & $\begin{array}{c}\text { Tỷ lệ tăng } \\
\text { GDP do } \\
\text { tăng NSLĐ } \\
(\%)\end{array}$ & $\begin{array}{c}\text { Hệ số } \\
\text { đóng } \\
\text { góp của } \\
\text { K }\end{array}$ & $\begin{array}{c}\text { Hệ số } \\
\text { đóng } \\
\text { góp của } \\
\mathbf{L}\end{array}$ & $\begin{array}{c}\text { Tốc độ } \\
\text { tăng GDP } \\
\text { do tăng K } \\
(\%)\end{array}$ & $\begin{array}{c}\text { Tốc độ̣ } \\
\text { tăng GDP } \\
\text { do tăng } \\
\text { NSLĐ (\%) }\end{array}$ & $\begin{array}{c}\text { Tăng BQ } \\
\text { các tỷ lệ K } \\
\text { và NSLĐ } \\
(\%)\end{array}$ \\
\hline 2013 & 7.4388 & 8.8006 & 0.1240 & 0.8760 & 0.9224 & 7.7093 & 8.6317 \\
2014 & 0.5943 & 6.3203 & 0.0738 & 0.9262 & 0.0439 & 5.8539 & 5.8977 \\
2015 & -4.3625 & 3.5198 & 0.0317 & 0.9683 & -0.1383 & 3.4082 & 3.2699 \\
2016 & -2.3268 & 5.1491 & 0.0383 & 0.9617 & -0.0891 & 4.9519 & 4.8628 \\
2017 & -1.0191 & 3.8068 & 0.0279 & 0.9721 & -0.0284 & 3.7006 & 3.6722 \\
\hline
\end{tabular}

Nguồn: Tính toán từ số liệu Niên giám thống kê các tỉnh, thành phố của vùng KTTĐ phía Nam

Qua Bảng 9 cho thấy, năm 2013 và 2014, năng suất vốn đầu tư tăng, nhưng 3 năm sau từ năm 2015 đến năm 2017 năng suất vốn đầu tư đều giảm đi và làm giảm khá nhiều về tổng sản phẩm của vùng KTTĐ phía Nam, tuy nhiên mức giảm có nhỏ dần qua các năm; ngược lại NSLĐ thì liên tục tăng lên và làm tăng tổng sản phẩm của vùng với xu hướng thấp dần. Như vậy, tổng sản phẩm của vùng tăng lên do tăng NSLĐ cao hơn mức giảm đi của tổng sản phẩm của vùng do giảm năng suất vốn đầu tư, nhưng năng suất bình quân chung, tức là tốc độ tăng năng suất nhân tố tổng hợp có xu hướng giảm.

(iii) Về tiến bộ khoa học công nghệ: Yếu tố cơ bản trong TFP là tiến bộ khoa học công nghệ. Tiến bộ khoa học công nghệ có tác động làm tăng năng suất lao động và nâng cao hiệu quả đầu tư, thúc đẩy đóng góp của yếu tố TFP trong tăng trưởng kinh tế vùng.

Đầu tư vào nghiên cứu, phát triển và ứng dụng khoa học công nghệ vào sản xuất của vùng KTTĐ phía Nam trong những năm qua mặc dù đã có những tiến triển khả quan, tác động đến tăng trưởng trong nhiều lĩnh vực, góp phần tạo ra nhiều sản phẩm mới, có giá trị kinh tế cao, song vẫn chưa tạo nên bước đột phá trong tỷ lệ đóng góp của tiến bộ khoa học công nghệ vào tăng trưởng. Theo tiêu chí đầu tư cho $R \& D$ bình quân trên cán bộ nghiên cứu của vùng thấp. Đáng lưu ý là đầu tư $\mathrm{R} \& \mathrm{D}$ của $\mathrm{khu}$ vực ngoài Nhà nước đang còn quá thấp, mới đạt khoảng $21 \%$.

Số lượng các bằng phát minh sáng chế trên một người dân chỉ bằng $1 / 10$ so với Trung Quốc và Thái Lan, bằng $1 / 85$ so với Singapore. Năng lực nghiên cứu cơ bản và phát triển công nghệ mặc dù được đánh giá là có tiến bộ khả quan song mới chỉ thể hiện dưới dạng tiềm năng. Số lượng các cơ quan khoa học công nghệ so với các nước là không nhiều, trình độ của cán bộ làm nghiên cứu khoa học công nghệ còn thấp so với nhiều nước trong khu vực và khả năng đáp ứng nhu cầu xã hội còn hạn chế. 
Trình độ công nghệ của vùng còn thấp, lạc hậu vài chục năm so với những nước công nghiệp phát triển, đứng thứ 92 trong số 117 nước được điều tra (WEF, 2014 - 2015). Công nghệ trong các doanh nghiệp lạc hậu so với khu vực. Chuyển giao công nghệ chưa có những tiến bộ cần thiết, đặc biệt trình độ công nghệ thông tin còn thấp. Tỷ trọng doanh nghiệp có công nghệ cao mới đạt $24,8 \%$; rất ít doanh nghiệp quan tâm đến thông tin về khoa học và công nghệ, chỉ có khoảng $12 \%$ doanh nghiệp đạt được trình độ tiên tiến (phần lớn là doanh nghiệp có vốn đầu tư nước ngoài).

\subsection{Năng lục cạnh tranh của các tỉnh, thành phố của vùng KTTÐ phía Nam}

Tăng trưởng về chất phải là quá trình tăng trưởng theo chiều sâu, đảm bảo nâng cao hiệu quả và năng lực cạnh tranh của vùng KTTĐ phía Nam nói chung và của ngành, doanh nghiệp nói riêng. Đối với vùng KTTĐ phía Nam, mặc dù đã thực hiện nhiều giải pháp nhằm nâng cao năng lực cạnh tranh, nhưng nhìn chung, chất lượng, hiệu quả, sức cạnh tranh các tỉnh, thành phố của vùng vẫn chưa cao.

Có tất cả 10 chỉ số thành phần (với thang điểm 100) nhằm đánh giá và xếp hạng các tỉnh, thành phố về chất lượng điều hành cấp tỉnh tại Việt Nam. Những chỉ số đó là: (i) Gia nhập thị trường; (ii) tiếp cận đất đai và sự ổn định trong sử dụng đất; (iii) tính minh bạch; (iv) chi phí thời gian; (v) chi phí không chính thức; (vi) tính năng động và tiên phong của lãnh đạo tỉnh; (vii) cạnh tranh bình đẳng; (viii) dịch vụ hỗ trợ doanh nghiệp; (ix) đào tạo lao động; (x) thiết chế pháp lý. Xếp hạng năng lực cạnh tranh của các tỉnh, thành phố của vùng còn thấp và có năm tụt bậc trong bảng xếp hạng năng lực cạnh tranh toàn cầu của WEF trong những năm qua.

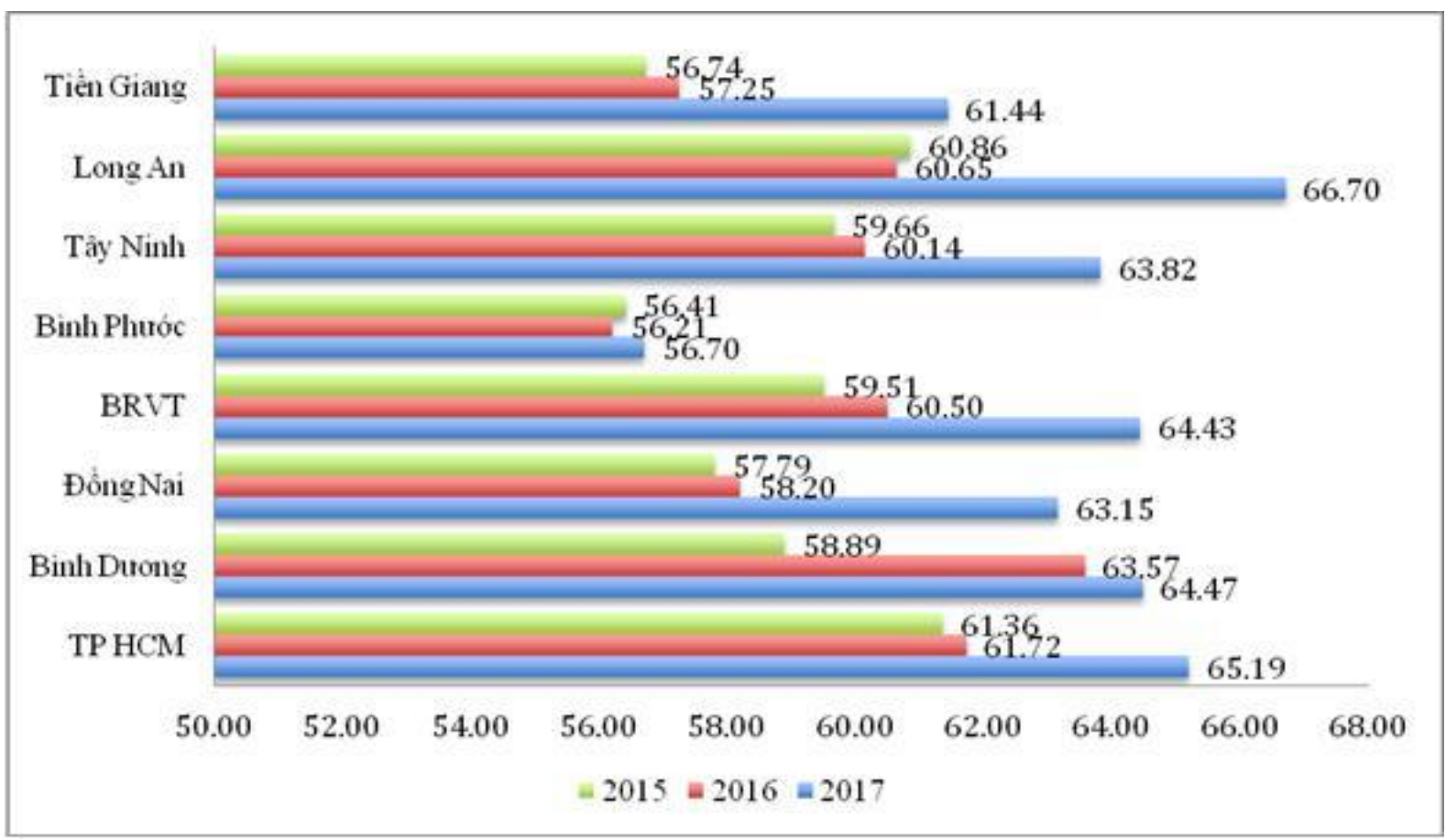

Hình 5. Chỉ số năng lực cạnh tranh các tỉnh, thành phố (PCI) của vùng KTTĐ phía Nam Nguồn: Phòng Thương mại và Công nghiệp Việt Nam (VCCI) và Cơ quan Phát triển Quốc tế Hoa Kỳ (USAID) 
Qua Hình 5 cho thấy, từ năm 2015 - 2017 thì hầu hết các tỉnh, thành phố của vùng KTTĐ phía Nam đều có chỉ số năng lực cạnh tranh tăng. Có tỉnh, thành phố tăng từ 4 đến 5 điểm. Mặc dù PCI của các tỉnh, thành phố có tăng nhưng khi xếp hạng so với 63 tỉnh, thành phố của cả nước thì có một số tỉnh, thành phố của vùng KTTĐ phía Nam tụt hạng trong bảng xếp hạng, cụ thể như tỉnh Bình Dương từ vị trí thứ 4 tụt đến vị trí thứ 14; tỉnh Bình Phước từ vị trí thứ 57 tụt đến vị trí thứ 62 so với cả nước. Ngoài ra qua bảng chỉ số và xếp hạng cũng cho thấy, sự chênh lệch về điểm số cũng như sự chênh lệch về vị trí xếp hạng của các tỉnh, thành phố của vùng là khá lớn như năm 2017. Điều này cho thấy, có sự khác biệt khá lớn về chất lượng điều hành của các tỉnh, thành phố của vùng KTTĐ phía Nam, do đó vấn đề đặt ra là cần phải có liên kết nội bộ vùng hay các tỉnh, thành phố của vùng để nâng cao năng lực cạnh tranh cũng như nâng cao chất lượng tăng trưởng kinh tế ổn định và bền vững của cả vùng.

\section{Bảng 10}

Xếp hạng chỉ số năng lực cạnh tranh các tỉnh, thành phố của vùng KTTĐ phía Nam so với 63 tỉnh, thành phố của cả nước

\begin{tabular}{|l|c|c|c|c|c|c|c|c|}
\hline \multicolumn{1}{|c|}{ Xếp hạng } & $\mathbf{2 0 1 0}$ & $\mathbf{2 0 1 1}$ & $\mathbf{2 0 1 2}$ & $\mathbf{2 0 1 3}$ & $\mathbf{2 0 1 4}$ & $\mathbf{2 0 1 5}$ & $\mathbf{2 0 1 6}$ & $\mathbf{2 0 1 7}$ \\
\hline TP HCM & $23 / 63$ & $20 / 63$ & $13 / 63$ & $10 / 63$ & $4 / 63$ & $6 / 63$ & $8 / 63$ & $8 / 63$ \\
\hline Bình Dương & $5 / 63$ & $24 / 63$ & $19 / 63$ & $30 / 63$ & $27 / 63$ & $25 / 63$ & $4 / 63$ & $14 / 63$ \\
\hline Đồng Nai & $25 / 63$ & $9 / 63$ & $9 / 63$ & $40 / 63$ & $42 / 63$ & $37 / 63$ & $34 / 63$ & $26 / 63$ \\
\hline BRVT & $19 / 63$ & $6 / 63$ & $21 / 63$ & $39 / 63$ & $24 / 63$ & $18 / 63$ & $16 / 63$ & $16 / 63$ \\
\hline Bình Phước & $36 / 63$ & $8 / 63$ & $39 / 63$ & $35 / 63$ & $38 / 63$ & $53 / 63$ & $57 / 63$ & $62 / 63$ \\
\hline Tây Ninh & $33 / 63$ & $26 / 63$ & $57 / 63$ & $11 / 63$ & $19 / 63$ & $16 / 63$ & $20 / 63$ & $19 / 63$ \\
\hline Long An & $12 / 63$ & $3 / 63$ & $16 / 63$ & $19 / 63$ & $7 / 63$ & $9 / 63$ & $15 / 63$ & $4 / 63$ \\
\hline Tiền Giang & $24 / 63$ & $33 / 63$ & $29 / 63$ & $37 / 63$ & $52 / 63$ & $48 / 63$ & $48 / 63$ & $40 / 63$ \\
\hline
\end{tabular}

Nguồn: Phòng Thương mại và Công nghiệp Việt Nam (VCCI) và Cơ quan Phát triển Quốc tế Hoa Kỳ (USAID)

Các tỉnh Bình Dương và Bình Phước có sự tụt giảm trong bảng xếp hạng là do các chỉ số năng lực cạnh tranh thành phần thấp, gồm có: chỉ số công nghệ - TI: Technology Index; chỉ số thể chế công - PII: Public Institution Index; chỉ số môi trường vĩ mô - MEI: Macroeconomic Environment Index.

Nguyên nhân dẫn đến xếp hạng chỉ số công nghệ của của các tỉnh, thành phố của vùng thấp là do trình độ công nghệ còn yếu kém. Mặc dù đã có nhiều tiến bộ đáng kể trong việc hoàn thiện hệ thống pháp luật và các chính sách cởi mở về xuất khẩu, song hệ thống pháp luật của nước ta vẫn còn tồn tại nhiều bất cập; còn thiếu tính nhất quán và ổn định. Việc thực thi pháp luật không nghiêm cũng được coi là một nguyên nhân. Nạn quan liêu, tham nhũng tuy đã có những biện pháp đấu tranh nhưng trong những năm gần đây vẫn còn khá phổ biến và nghiêm trọng, dẫn đến chỉ số về năng lực thể chế của nước ta còn thấp. Chỉ số về môi trường vĩ mô cũng ở vị trí khiêm tốn. Nguyên nhân do môi trường kinh doanh còn chưa thực sự bình đẳng, còn quá nhiều doanh nghiệp nhà nước độc quyền trên các lĩnh vực; tính minh bạch, công khai của nền kinh tế, bao gồm cả doanh nghiệp và cơ quan nhà nước còn thấp. 


\section{Kết luận và đề xuất một số giải pháp}

\subsection{Kết luận}

Từ phân tích, đánh giá thực trạng chất lượng tăng trưởng kinh tế của vùng KTTĐ phía Nam nhìn từ góc độ kinh tế cho thấy, so với các vùng KTTĐ khác của Việt Nam, Vùng KTTĐ phía Nam đang trong giai đoạn phát triển công nghiệp hóa mạnh mẽ, việc duy trì tốc độ tăng trưởng đang là mục tiêu trước mắt, cơ cấu kinh tế chuyển dịch đúng định hướng (năm 2017, tỷ trọng ngành dịch vụ là $42,79 \%$; công nghiệp và xây dựng là $40,43 \%$; nông, lâm nghiệp và thuỷ sản là 5,86\%) gắn với chuyển đổi mô hình tăng trưởng, cơ cấu lại kinh tế đạt kết quả bước đầu, góp phần cùng cả nước kiểm soát lạm phát, ổn định kinh tế vĩ mô. Nhiều chính sách hỗ trợ và khuyến khích đổi mới công nghệ, thu hút vốn đầu tư toàn xã hội đạt hiệu quả thiết thực. Môi trường đầu tư và kinh doanh ngày càng thuận lợi, minh bạch, hỗ trợ tích cực cho doanh nghiệp, tiếp tục khẳng định vị trí là vùng KTTĐ đầu tàu về kinh tế - xã hội của khu vực phía Nam và cả nước. Tuy nhiên, tăng trưởng của vùng có xu hướng chậm lại và thiếu bền vững (tốc độ tăng trưởng GDP từ năm 2016 là 6,92\%, đến năm 2017 giảm xuống còn 6,20\%); tỷ trọng đóng góp của yếu tố TFP trong GDP có xu hướng giảm (năm 2016 là 70,29\%, năm 2017 là 59,12\%); chất lượng tăng trưởng và năng lực cạnh tranh trong điều kiện hội nhập chưa cao; chuyển dịch cơ cấu nội bộ các ngành kinh tế còn chậm, hàm lượng khoa học - công nghệ trong giá trị sản phẩm còn thấp. Tiềm năng, lợi thế khai thác chưa đạt hiệu quả cao.

Vùng KTTĐ phía Nam đang áp dụng bài học thay thế ưu tiên tốc độ tăng trưởng bằng mục tiêu nâng cao chất lượng tăng trưởng để tạo cơ sở đạt được các mục tiêu về kinh tế - xã hội và rút ngắn khoảng cách phát triển, thoát khỏi nguy cơ tụt hậu trong quá trình hội nhập vào nền kinh tế thế giới. Song vẫn còn nhiều vấn đề đặt ra cần giải đáp. Vì vậy, chúng tôi đề xuất một số giải pháp để nâng cao chất lượng tăng trưởng kinh tế của vùng KTTĐ phía Nam.

\section{2. Đề xuất một số giải pháp}

Phát triển khoa học - công nghệ và nguồn nhân lực. Tăng cường đầu tư cho khoa học và công nghệ nhằm nâng cao năng suất lao động và hiệu quả sử dụng vốn; đầu tư có trọng tâm một số công nghệ cao có tác động tích cực đến nâng cao sức cạnh tranh và hiệu quả của vùng; đẩy mạnh hội nhập quốc tế trong lĩnh vực khoa học và công nghệ; xây dựng cơ chế tăng cường liên kết giữa nhà khoa học - nhà quản lý - doanh nghiệp, giữa khu công nghệ cao với các trường đại học, viện nghiên cứu, khu chế xuất và khu công nghiệp; gắn kết các hoạt động nghiên cứu khoa học - công nghệ với nhu cầu thực tiễn, khuyến khích, tạo điều kiện cho đầu tư, nghiên cứu, chuyển giao, ứng dụng tiến bộ khoa học kỹ thuật, đổi mới công nghệ, thương mại hóa sản phẩm công nghệ cao.

Đổi mới co chế huy động nguồn lực trong-ngoài nước và phát triển thị truờng vốn. Khơi thông các nguồn lực tích lũy và nhàn rỗi trong dân cư thông qua xã hội hóa đầu tư. Phát triển thị trường chứng khoán, trái phiếu doanh nghiệp để tạo điều kiện cho doanh nghiệp huy động nguồn lực xã hội; các địa phương của vùng tìm kiếm nhà đầu tư có năng lực và thực hiện hiệu quả chủ trương xã hội hóa cho tất cả các ngành, lĩnh vực thông qua phương thức đầu tư đối tác 
công - tư (PPP), kích cầu nguồn vốn xã hội để giảm áp lực ngân sách địa phương. Đồng thời, tổ chức kết nối nhà đầu tư với ngân hàng, các tổ chức tín dụng, hỗ trợ các doanh nghiệp tiếp cận các nguồn vốn vay, đơn giản hóa thủ tục...

Cải thiện môi truờng đầu tu, mở rộng hợp tác quốc tế và khai thác lợi thế của vùng. Xây dựng môi trường đầu tư ổn định, an toàn, bảo vệ quyền sở hữu tài sản hợp pháp, sở hữu trí tuệ và quyền tự do kinh doanh của người dân, doanh nghiệp và không hình sự hóa các quan hệ kinh tế, dân sự; tăng cường hoạt động hỗ trợ khởi nghiệp từ ngân sách để hỗ trợ khởi nghiệp và hỗ trợ các hộ kinh doanh cá thể chuyển sang doanh nghiệp; bổ sung các dự án khởi nghiệp vào chương trình kích cầu đầu tư; áp dụng mô hình quản trị hiện đại, đầu tư hiện đại hóa trang thiết bị thông qua chương trình kích cầu đầu tư, chương trình kết nối ngân hàng - doanh nghiệp; bình đẳng trong tiếp cận các nguồn lực của từng địa phương.

Phát triển cơ sở hạ tầng. Tập trung nguồn lực của Nhà nước để đầu tư, đồng bộ hóa hạ tầng kinh tế - xã hội, nhất là kết cấu hạ tầng giao thông trọng điểm, có tác dụng lan tỏa, tạo ra liên kết vùng (các công trình trên trục hướng tâm, các vành đai, các đường kết nối các cảng biển và hành lang vận tải quốc tế); ưu tiên đầu tư các tuyến trục và các tuyến vành đai nhằm củng cố mối liên kết giữa trung tâm với vùng ngoại vi và giải tỏa ách tắc; mở các tuyến cao tốc mới nối kết hệ thống giao thông với hệ thống cụm cảng - logistics của TP HCM, tỉnh Đồng Nai và BRVT.

Phát huy lợi thế của hội nhập để phát triển doanh nghiệp. Tăng cường hợp tác liên vùng thông qua các chương trình hợp tác và phối hợp phát triển liên vùng. Có biện pháp khuyến khích thu hút vốn của các doanh nghiệp từ TP $\mathrm{HCM}$ và Đông Nam bộ cũng như các vùng khác nhằm ưu tiên phát triển các sản phẩm chủ lực; phát triển, đa dạng hóa các loại hình thương mại bán lẻ hiện đại, thương mại điện tử, sản phẩm và thị trường xuất khẩu, trong đó các doanh nghiệp bán lẻ trong nước đóng vai trò chủ đạo định hướng và dẫn dắt thị trường; phát triển du lịch kết hợp đầu tư, mua sắm, chữa bệnh; chú trọng phát triển mạnh các ngành dịch vụ công nghệ cao theo kịp trình độ tiên tiến của khu vực và thế giới như viễn thông, ngân hàng, thương mại, du lịch lữ hành, khách sạn nhà hàng và dịch vụ nhà ở, nhằm nâng cao hiệu quả kinh tế của sản xuất công nghiệp - nông nghiệp, gắn sản xuất với thị trường trong và ngoài nước; ưu tiên phát triển mạng lưới trung tâm logistics như: dịch vụ kho, bãi hiện đại, cảng vận tải, hậu cần hàng hải và xuất - nhập khẩu của vùng.

\section{Tài liệu tham khảo}

Bộ Kế hoạch và Đầu tư. (2012). Thông tu Số 02/2012/TT-BKHĐT Ban hành Quy định năm 2010 làm năm gốc thay cho năm gốc 1994 để tính các chỉ tiêu thống kê theo giá so sánh [Circular No. 02/2012 / TT-BKHDT Promulgating the 2010 regulation as the base year to replace the 1994 base year for calculating statistical indicators at constant prices]. Retrieved May 20, 2019, from https://thuvienphapluat.vn/van-ban/linh-vuc-khac/Thongtu-02-2012-TT-BKHDT-nam-2010-lam-nam-goc-thay-cho-nam-goc-1994-137660.aspx 
Cobb, C. W., \& Douglas, P. H. (1928). A theory of production. American Economic Review, 8, 1939-1965.

Dinh, H. P., \& Nguyen, P. V. (2015). Sách chuyên khảo Kinh tế phát triển căn bản và nâng cao [Monograph book on basic and advanced development economics]. Ho Chi Minh, Vietnam: NXB Kinh tế.

Ha, D. T. T., \& Nguyen, K. D. (2014). Vai trò của vốn con người đối với tăng trưởng kinh tế vùng Duyên Hải Nam Trung Bộ [The role of human capital in economic growth in the South Central Coast]. Tạp chí Phát triển Kinh tế, 283, 3-19.

Krueger, A. B., \& Lindahl, M. (2001). Education for growth: Why and for whom? Journal of Economic Literature, 39(4), 1101-1136.

Ng, Y. C., \& Leung, C. M. (2004). Regional economic performance in China: A panel data estimation. Paper presented at Hong Kong Baptist University, Hong Kong.

Nguyen, A. T. T. (2006). Tác động của đầu tu trục tiếp nước ngoài tới tăng trương kinh tế ở Việt Nam [The impact of foreign direct investment on economic growth in Vietnam]. Hanoi, Vietnam: NXB Khoa học và Kỹ thuật.

Nguyen, A. T. T., \& Le, B. X. (2005). Chất lựng tăng trương kinh tế, Một số đánh giá ban đầu [Quality of economic growth, Some initial reviews]. Retrieved June 21, 2019, from http://www.ciem.org.vn/Portals/0/CIEM/BaoCaoKhoaHoc/2005/RRChat_luong_tang_t ruong_2005_23306.pdf

Nguyen, H. T. (2013). Giáo trình Kinh tế phát triển [Textbook of development economics]. Ho Chi Minh, Vetnam: NXB Kinh tế.

Nguyen, H. T. (2017). Sách chuyên khảo các chủ đề phát triển chọn lọc khung phân tích và bằng chứng thục nghiệm cho Việt Nam [Monograph on development topics, a selective analytical framework and empirical evidence for Vietnam]. Ho Chi Minh, Vietnam: NXB Kinh tế.

Nguyen, N. H. (2015). Sách chuyên khảo thể chế và chất lự̛ng tăng truởng kinh tế tại Việt Nam [Monograph on institutions and quality of economic growth in Vietnam]. Ho Chi Minh, Vietnam: NXB Đại học Quốc gia TP. HCM.

Solow, Robert M. (1957). Technical change and the aggregate production function. Review of Economics and Statistics, 39, 312-320.

Tang, K. V. (2018). Tốc độ tăng năng suất các nhân tố tổng hợp. Phương pháp tính và ưng dung [Aggregate factor productivity increases. Calculation method and application]. Hanoi, Vietnam: NXB Thống Kê. 
Tổng cục thống kê. (2010). Báo cáo Năng suất lao động của Việt Nam/Vietnam Labor Productivity Report]. Retrieved May 25, 2019, from https://www.gso.gov.vn/wpcontent/uploads/2019/05/2-Bao-cao-Nang-suat-lao-dong-cua-Viet-Nam.pdf

Tran, D. T. (2010). Vai trò vốn con người trong các mô hình tăng trưởng [The role of human capital in growth models]. Tạp chí Nghiên cứu kinh tế, 393, 3-10.

World Bank (2012). World Development Indicators. CD-ROM. Retrieved June 25, 2019, from https://documents.worldbank.org/en/publication/documentsreports/documentdetail/553131468163740875/world-development-indicators-2012

World Economic Forum (WEF). (2014-2015). The global competitiveness report (2014-2015). Retrieved June 25, 2019, from http://www3.weforum.org/docs/WEF_GlobalCompetitivenessReport_2014-15.pdf 